\title{
Corn and Soybean Yields as AfFected By Cover Crops and Herbicide Timing Under No-Tillage SYSTEM ${ }^{1}$
}

\author{
Produtividade de Milho e Soja em Função de Plantas de Cobertura e Época de Aplicação de \\ Herbicida no Sistema Plantio Direto
}

OLIVEIRA, P. ${ }^{2}$, NASCENTE, A.S. ${ }^{3}$, KLUTHCOUSKI, J. ${ }^{3}$, and CASTRO, T.A.P. ${ }^{4}$

\begin{abstract}
To achieve better results in the no-tillage system (NTS), it is important to properly manage the cover crop prior to planting by using herbicides, usually glyphosate. The effect of glyphosate on plant coverage is slow, and plants take a few days to die completely. Thus, when applying the herbicide on the same day of planting soybean or corn, cover crops are still alive and standing, causing initial shading on seedlings of the crop and delaying its establishment. Therefore, this study aimed to evaluate the effect of distinct cover crops and their timing of desiccation prior to planting soybean or corn, on crop yield and yield components. Two experiments were installed, one for soybean and another for corn. Each experiment consisted in combining three cover crops (Brachiaria brizantha, common bean or millet) chemically desiccated at two timings before planting the crop (15 or 0 days before planting) under no-tillage system (NTS). Experiments were installed in a completely randomized block design with five replications. Brachiaria brizantha produced the highest amount of biomass; common bean and millet as cover crops allowed higher soybean grain yields; herbicide application under common bean, millet and Brachiaria brizantha 15 days before planting soybean allowed higher crop grain yields; desiccation timing of common bean did not affect corn grain yield; Brachiaria brizantha should be desiccated 15 days before planting corn to allow maximum grain yield; when millet was used as a cover crop, glyphosate application at planting of corn allowed the highest grain yield.
\end{abstract}

Keywords: Brachiaria brizantha, Pennisetum glaucum, Phaseolus vulgaris, Zea mays, Glycine max, herbicide timing.

\begin{abstract}
RESUMO - Para alcançar melhores resultados no sistema plantio direto (SPD), é importante o adequado manejo das plantas de cobertura com herbicida, normalmente o glifosato. O efeito do glifosato nas plantas de cobertura é lento e essas coberturas demoram alguns dias para morrer completamente. Dessa forma, quando se aplica o herbicida no mesmo dia do plantio do milho ou soja, as plantas de cobertura ainda estão vivas e eretas. Isso pode causar sombreamento inicial nas plântulas de soja ou milho e prejudicar o desenvolvimento inicial que pode causar redução na produtividade. Assim, objetivou-se com este trabalho avaliar o efeito de plantas de cobertura e a época de aplicação de herbicidas antes do plantio sobre os componentes do rendimento e produtividade da soja e milho. $O$ experimento consistiu na avaliação de 3 plantas de cobertura (Brachiaria brizantha, feijäo e milheto) $x$ duas épocas de aplicação de herbicida (15 e 0 dias antes do plantio da soja ou milho) no sistema plantio direto em blocos ao acaso com cinco repetições. Brachiaria brizantha produziu maior quantidade de biomassa; feijão e milheto como culturas de cobertura proporcionaram maior produtividade de grãos de soja; a aplicação do herbicida em feijão, milho e Brachiaria brizantha 15 dias antes do plantio da soja proporcionou maior produtividade da cultura; feijão como planta de cobertura dessecada 15 ou $O$ dias antes da semeadura do milho, acarretou em maior produtividade do milho; Brachiaria brizantha deve ser dessecada 15 dias antes da semeadura do milho, para
\end{abstract}

Recebido para publicação em 2.10.2012 e aprovado em 21.2.2013.

2 Embrapa Cerrados, Planaltina-DF, Brasil, <priscila.oliveira@embrapa.br>; ${ }^{3}$ Embrapa Arroz e Feijão, Santo Antônio de Goiás-GO, Brasil; ${ }^{4}$ Universidade Federal de Goiás, Goiânia-GO, Brasil. 
permitir maior produtividade de grãos; a aplicação de glifosato no milheto no dia do plantio do milho acarretou em maior produtividade de grãos de milho.

Palavras-chave: Brachiaria brizantha, Pennisetum glaucum, Phaseolus vulgaris, Zea mays, Glycine max, época aplicação de herbicida.

\section{INTRODUCTION}

No-tillage systems (NTS) have been largely responsible for the significant increase in crop yields and continuity of agricultural development in the tropics (Crusciol et al., 2012; Nascente et al., 2013a). Such systems are sustainable because of untilled soils and crop rotation that provide permanent maintenance of straw on the soil surface (Sulc and Tracy, 2007; Nascente and Crusciol, 2012; Nascente et al., 2013c). Soybean and corn are the most important cash crops planted in soil under NTS, which is becoming an important kind of soil management practice in Brazil (Conab, 2012).

However, to achieve better results in the NTS, proper management of the cover crop and use of herbicide are essential (Nascente et al., 2013b). The management of cover crops before planting crops is done with total systemic herbicide action, with glyphosate being the most widely used (Nascente and Crusciol, 2012; Nascente et al., 2012). This herbicide has broad spectrum of action, normally allowing control of annual and perennial weeds and cover crops (Yamada and Castro, 2007). However, the effect of glyphosate on plant coverage is slow and those coverages take a few days to die completely (Constantin et al., 2008). Thus, when applying herbicide on the same day of planting soybean or corn, cover crops are still alive and standing. So, it can cause initial shading on corn or soybean seedlings, harming their initial development (Nascente et al., 2012). There are reports of farmers describing effects such as yellowing, shading, reduced development and reduction in crop production (Constantin et al., 2008). Furthermore, according to Coupland and Lutman (1982) in glyphosate applications near the planting time, there is the possibility of root exudation of herbicides from cover crops to corn or soybean, especially if the roots of cover crops treated with herbicide are numerous and close to the roots of crops. Research showed that the best time to dry out the weeds or cover crops ranges between seven and 20 days before planting soybeans or corn (Constantin et al., 2009; Nunes et al., 2009; Monquero et al., 2010; Nascente et al., 2012).

However, it is possible that the species of cover crop would affect the crops corn or soybean differently and, therefore, it must have been desiccated at a different time. The right management of cover crops with chemicals can provide higher availability of nutrients due to their degradation, greater persistence of straw on the soil surface and lower release of possible allelopathic substances to the soil (Yamada and Castro, 2007; Nascente et al., 2013b). It is also very important to determine which cover crops are the best to promote higher corn and soybean productivity. This study aimed to evaluate the effect of distinct cover crops and their timing of desiccation prior to planting soybean or corn, on crop yield and yield components.

\section{MATERIAL AND METHODS}

The field experiment was conducted in 2007/2008 in Santo Antônio de Goiás, GO $\left(16^{\circ} 27^{\prime} \mathrm{S} 49^{\circ} 17^{\prime} \mathrm{W}\right.$ at $823 \mathrm{~m}$ altitude). The regional climate is tropical savanna, classified as Aw according to the Köppen classification with two well defined seasons, with the annual average temperature ranging from 20.6 to $23.2^{\circ} \mathrm{C}$ and annual precipitation of $1.485 \mathrm{~mm}$. The soil was an Oxisol with gently undulating topography. Soil texture was clayey (540 g kg-1 clay, $\mathrm{g} \mathrm{kg}^{-1}$ silt and $35 \mathrm{~g} \mathrm{~kg}^{-1}$ sand). Regarding soil analysis (Table 1), $\mathrm{P}$ and $\mathrm{K}$ were extracted by Mehlich-1 extracting solution (0.05M HC1 in $\left.0.0125 \mathrm{M} \mathrm{H}_{2} \mathrm{SO}_{4}\right)$. Phosphorus was determined colorimetrically and $\mathrm{K}$ by flame photometry. Calcium, $\mathrm{Mg}$, and $\mathrm{Al}$ were extracted with $1 \mathrm{M} \mathrm{KC} 1$. Aluminum was determined by titration with $\mathrm{NaOH}$ and $\mathrm{Ca}$ and $\mathrm{Mg}$ by titration with EDTA. 
Table 1 - Chemical properties of the soil in the experimental area

\begin{tabular}{|c|c|c|c|c|c|c|c|c|c|c|c|c|c|c|}
\hline Depth & $\mathrm{pH}$ & $\mathrm{Ca}$ & $\mathrm{Mg}$ & $\mathrm{Al}$ & $\mathrm{H}+\mathrm{Al}$ & $\mathrm{P}$ & $\mathrm{K}$ & $\mathrm{Cu}$ & $\mathrm{Zn}$ & $\mathrm{Fe}$ & $\mathrm{Mn}$ & $\mathrm{MO}$ \\
\hline$(\mathrm{cm})$ & (water) & \multicolumn{8}{c|}{$\left(\mathrm{mg} \mathrm{dm}^{-3}\right)$} & $\left(\mathrm{g} \mathrm{dm}^{-3}\right)$ \\
\hline \multicolumn{8}{|c|}{$\left(\mathrm{cmol}_{\mathrm{c}} \mathrm{dm}^{-3}\right)$} \\
\hline 0
\end{tabular}

The study was conducted in an area that had been cultivated in NTS for one year, with the following history: bean in the winter (2006), corn and Brachiaria brizantha intercropped in the summer (2006/2007). Bean, millet and $B$. brizantha in the winter, each species in $1 / 3$ of the area for producing straw to the experiment.

Two experiments were conducted, one for corn and another for soybean, with the same experimental design. i.e., a randomized block design with three replications in a $3 \times 2$ factorial arrangement (3 cover crops $\mathrm{x} 2$ desiccation times) in a no-tillage system. The plots measured $5.4 \mathrm{~m} \times 6.0 \mathrm{~m}$, with a total area of $32.4 \mathrm{~m}^{2}$. The usable area was the three central rows eliminating $0.50 \mathrm{~m}$ at the end of each row. The cover crops used were: 1 , common bean (Phaseolus vulgaris); 2, millet (Pennisetum glaucum) and Brachiaria brizantha - cv. Marandu. Cover crops were desiccated at 15 and 0 days before plantingof soybean or corn by applying herbicide glyphosate at $1.8 \mathrm{~kg} \mathrm{ha}^{-}$ ${ }^{1}$ acid equivalent using a boom sprayer with spray volume of 200 liters ha ${ }^{-1}$. Environmental conditions during pulverization were weak winds, temperature around $25^{\circ} \mathrm{C}$ and relative humidity around $80 \%$. This procedure was done after drying the dew of cover crop leaves.

Soybean was sowed on $24^{\text {th }}$ November of 2007, using the cultivar BRS Valiosa RR in $0.45 \mathrm{~m}$ with 20 viable seeds per meter. The furrow openers, fertilizer distribution and soybean seeding were performed with a Semeato ${ }^{\circledR}$ tractor-mounted planter model Personale DRILL-13. $300 \mathrm{~kg} \mathrm{ha}^{-1}$ of NPK formula 05-30-15 was used and other cultural practices were performed as recommended for the culture. Emergence of soybean seedlings occurred seven days after planting. Weed control was done applying $0.6 \mathrm{~g}$ e.a. ha of glyphosate 12 days after emergence.

Corn was sowed on $24^{\text {th }}$ November 2007 , using the hybrid BRS 1030 in $0.90 \mathrm{~m}$ with 7 viable seeds per meter. The furrow openers, fertilizer distribution and corn planting, were performed with a Semeato ${ }^{\circledR}$ tractor-mounted planter model Personale DRILL-13. $300 \mathrm{~kg} \mathrm{ha}^{-1}$ of NPK formula 05-30-15 was used and other cultural practices were performed in accordance as recommended for the culture. Emergence of corn seedlings occurred six days after planting. At this time, corn topdressing fertilization was performed by using $67.5 \mathrm{~kg} \mathrm{ha}^{-1}$ of Nitrogen as urea, incorporated mechanically at $5 \mathrm{~cm}$ depth. Weed control was done by applying $0.6 \mathrm{~L} \mathrm{ha}^{-1}$ of Nicosulfuron $+3.0 \mathrm{~L} \mathrm{ha}^{-1}$ of Atrazine 12 days after emergence.

Cover crops were sampled at desiccation time, from a $1.0 \mathrm{~m} \times 1.0 \mathrm{~m}$ area selected randomly and sampled four times in each plot. The collected plant material was placed in paper bags and dried in a forced ventilation oven at $65{ }^{\circ} \mathrm{C}$ and weighed; dry matter was converted to $\mathrm{Mg} \mathrm{ha}^{-1}$. 
At harvest maturity, soybeans and corn were harvested by hand in three $5 \mathrm{~m}$-rows. Plants were threshed and grain weight was determined, and data were transformed to grain yield per hectare (130 $\mathrm{g} \mathrm{kg}^{-1}$ wet basis). At this time, the final plant population was determined (counting the number of plants in the three central rows in five-meter rows in each plot, then extrapolating them to the hectare), plant height, number of ear $\mathrm{m}^{-2}$, number of ears per plant, number of grains per ear, and weight of 100 grains, evaluated from 10 plants per plot chosen at random in the usable area. For soybean, the following soybean agronomic characteristics were assessed: final population of plants (counting the number of plants in the two central rows from five-meters within each plot, then extrapolating them to the hectare), height of plant, number of pods per plant and number of grains per pod evaluated in 10 plants per plot chosen at random; and weight of 100 grains carried out by randomly collecting eight samples per plot.

The data for each crop (corn or soybean) was analyzed separately. Thus, for cover crop and crops data the two-way analysis of variance was performed with the Statistical Software Package SAS (SAS, 1999). Cover crops and desiccation time were considered independent factors. Mean separations were conducted using Tukey's test at $\mathrm{p} \leq 0.05$.

\section{RESULTS AND DISCUSSION}

There was only the main effect for the factors cover crops species and desiccation time for the variable amount of dry matter produced by the cover crops, and there was no interaction between these factors (Tabela 2). In this sense, herbicide applied before crop planting significantly reduced the amount of biomass on the soil surface. Besides, it could be observed that Brachiaria brizantha produced a bigger amount of dry matter in both evaluations $\left(6,547\right.$ and $7,968 \mathrm{Mg} \mathrm{ha}^{-1}$ for 15 and 0 days before crop planting) than millet $\left(4,101\right.$ and $5,032 \mathrm{Mg} \mathrm{ha}^{-1}$ for 15 and 0 days before crop planting) and common bean $(3,937$ and 4,424 $\mathrm{Mg} \mathrm{ha}^{-1}$ for 15 and 0 days before crop planting). $B$. brizantha is well-known for producing high amount of biomass that can be used as straw in the no-tillage system (NTS) (Crusciol et al., 2012; Nascente and Crusciol, 2012). In NTS, cover crops that produce large amounts of dry matter are desirable to favor a suitable ground cover (Nunes et al., 2006; Nunes et al., 2009; Ferreira et al., 2010). Despite the lowest amount of biomass produced by millet and common bean, the amount of straw is relevant. According to Lopes et al. (1987), biomass equivalent to 4.0-5.0 $\mathrm{Mg} \mathrm{ha}^{-1}$ is enough to cover about $70-85 \%$ of the soil.

It should be noted that there is a marked effect of glyphosate application on the amount of straw (Table 2). Plants desiccated 15 days before crop planting stopped growing and therefore produced a lower amount of biomass. On the other hand, cover crops desiccated on the crop planting day grew for 15 more days and had a higher amount of biomass. In this sense, $B$. brizantha accumulated more biomass during this interval $(7,968-6,547=$ 1,421 $\mathrm{Mg} \mathrm{ha}^{-1}$ ) than millet (931 $\mathrm{Mg} \mathrm{ha}^{-1}$ ) and common bean (487 $\mathrm{Mg}^{-1} \mathrm{ha}^{-1}$ ).

As regards soybean crop, plant population was not affected by the cover crops, desiccation time and interaction (Table 3). Also Nascente and Crusciol (2012) reported that the amount of $7.6 \mathrm{Mg} \mathrm{ha}^{-1}$ of $B$. brizantha and $2.8 \mathrm{Mg} \mathrm{ha}^{-1}$ of millet did not affect soybean plant population. On the other hand, Monquero et al. (2010) observed that desiccation done close to the soybean planting day caused reduction in the plant stand. Moreover, when the herbicide was applied near the seeding of soybeans, cover crops were not dry enough to allow the straw to be cut by the planter disks (Nascente and Crusciol, 2012). Therefore, the inadequate

Table 2 - Dry matter of cover crops on the soil surface when glyphosate was applied

\begin{tabular}{|l|c|c|}
\hline \multirow{2}{*}{ Cover crops } & \multicolumn{2}{|c|}{$\begin{array}{c}\text { Dessication time } \\
\text { (days before planting) }\end{array}$} \\
\cline { 2 - 3 } & 15 days & 0 day \\
\cline { 2 - 3 } & \multicolumn{2}{|c|}{$\left(\mathrm{mg} \mathrm{ha}^{-1}\right)$} \\
\hline Brachiaria brizantha & $6547 \mathrm{a} \mathrm{B}^{*}$ & $7968 \mathrm{a} \mathrm{A}$ \\
\hline Millet & $4101 \mathrm{~b} \mathrm{~B}$ & $5032 \mathrm{~b} \mathrm{~A}$ \\
\hline Common bean & $3937 \mathrm{~b} \mathrm{~B}$ & $4424 \mathrm{~b} \mathrm{~A}$ \\
\hline \multicolumn{1}{|c|}{$\mathrm{P}$} & $<0.001$ & $<0.001$ \\
\hline
\end{tabular}

* Means followed by the same letter vertically do not differ by Tukey's test at $5 \%$ probability. 
Table 3 - Plant population (POP), plant height (PH), number of pod per plant (POD), number of grain pod ${ }^{-1}$ (GRAIN), 100 grain weight (W100) and yield of soybean as a function of the cover crops and desiccation time of these cover crops (days before planting, DBP)

\begin{tabular}{|c|c|c|c|c|c|c|}
\hline Treatments & POP & $\mathrm{pH}$ & POD & Grain & W100 & YIELD \\
\hline Cover crops & (plant $\mathrm{m}^{-1}$ ) & $(\mathrm{cm})$ & ( $\mathrm{n}^{\circ}$ per plant $)$ & $\left(n^{o} \operatorname{pod}^{-1}\right)$ & (grams) & $\left(\mathrm{kg} \mathrm{ha}^{-1}\right)$ \\
\hline Brachiaria brizantha & $11 \mathrm{a}^{*}$ & $75 \mathrm{~b}$ & $57 \mathrm{c}$ & $2 \mathrm{a}$ & $34 \mathrm{~b}$ & $3631 \mathrm{~b}$ \\
\hline Millet & $10 \mathrm{a}$ & $82 \mathrm{a}$ & $63 \mathrm{~b}$ & $2 \mathrm{a}$ & $39 \mathrm{a}$ & $4588 \mathrm{a}$ \\
\hline Common bean & $9 \mathrm{a}$ & $77 \mathrm{~b}$ & $92 \mathrm{a}$ & $2 a$ & $37 \mathrm{a}$ & $4979 \mathrm{a}$ \\
\hline \multicolumn{7}{|c|}{ Desiccation time } \\
\hline $15 \mathrm{DBP}$ & $10 \mathrm{a}$ & $82 \mathrm{a}$ & $77 \mathrm{a}$ & $2 \mathrm{a}$ & $39 \mathrm{a}$ & $4646 \mathrm{a}$ \\
\hline \multirow[t]{2}{*}{0 DBP } & $10 \mathrm{a}$ & $74 \mathrm{~b}$ & $65 \mathrm{~b}$ & $2 \mathrm{a}$ & $34 \mathrm{~b}$ & $4153 \mathrm{~b}$ \\
\hline & \multicolumn{6}{|c|}{ ANOVA ( $F$ probability $)$} \\
\hline Cover crops (CC) & 0.5132 & 0.0477 & 0.0315 & 0.4210 & 0.0334 & 0.0408 \\
\hline Desiccation time (DT) & 0.2487 & $<0.0001$ & 0.0378 & 0.3351 & 0.0442 & 0.0416 \\
\hline CC x IT & 0.2589 & 0.1696 & 0.1811 & 0.1892 & 0.2340 & 0.2727 \\
\hline
\end{tabular}

* Means followed by the same letter vertically do not differ by Tukey’s test at 5\% probability

time to herbicide management could cause a minor seeding efficiency due to the difficulty of cutting and bushing or it might cause initial shadow on the soybean seedling with significant effect in the grain yield (Grisso et al., 2009; Nascente and Crusciol, 2012).

For plant height, there were the main effects of cover crops and desiccation time without interactions (Table 3). Millet allowed higher plant height $(82 \mathrm{~cm})$ than under $B$. brizantha $(75 \mathrm{~cm})$ and common bean $(77 \mathrm{~cm})$. At desiccation time done 15 days before planting observed higher soybean plant height $(82 \mathrm{~cm})$ than at soybean planting day $(65 \mathrm{~cm})$. According to Timossi et al. (2007) and Nascente et al. (2012), desiccation time close to planting date could increase the competition between species and reduce plant development.

As for the soybean yield component number of pod per plant, higher values were observed under common bean (92), followed by millet (63) and $B$. brizantha (57) (Table 3). The same trend happened in the 100 grain weight where $B$. brizantha had the lowest values (34 g) differing from the other cover crops. These differences had significant effect on the grain yield and $B$. brizantha straw allowed the lowest yield $\left(3,631 \mathrm{~kg} \mathrm{ha}^{-1}\right)$ differing from the cover crops millet $\left(4,588 \mathrm{~kg} \mathrm{ha}^{-1}\right)$ and common bean $\left(4,979 \mathrm{~kg} \mathrm{ha}^{-1}\right)$. This could be associated with the amount of straw on the soil surface, because a large amount of straw can affect plant growth and affect yield and yield components (Monquero et al., 2010; Nascente and Crusciol, 2012; Nascente et al., 2013b). Constantin et al. (2009) found that soybeans emerging on soil with a big amount of cover crop biomass had their productivity reduced. They showed that in addition to cover crops shadow, there are other factors such as the demand for nitrogen by the microorganism decomposing straw and allelopathic effects. Besides, according to Monquero et al. (2010), $B$. brizantha is less sensitive to glyphosate application than millet and, therefore, it takes more days to dry completely.

Yamada and Castro (2007) reported that the injury caused by the cover crops as a result of herbicide application close to planting the next summer crop could be aggravated by the higher dry matter production of the cover crops. In addition, millet and common bean are more sensitive to glyphosate and could be desiccated closer to soybean planting. Supporting this information, Monquero et al. (2010) reported that millet dried much faster than $B$. brizantha after glyphosate application. Therefore, during this time, without being completely dried, the perennial grass could damage the soybean development. Therefore, if the perennial grass were not completely dried at the planting day, it could damage soybean development. 
When the interval between cover crop desiccation and soybean planting was evaluated, it could be seen that 15 days before planting allowed a bigger number of pods per plant (77), higher 100-grain weight (39) and, as a result, higher grain yield $\left(4,646 \mathrm{~kg} \mathrm{ha}^{-1}\right)$ than desiccation done at soybean planting day $\left(4,153 \mathrm{~kg} \mathrm{ha}^{-1}\right)$. Nunes et al. (2009) add that the best time to apply glyphosate was between 7 and 14 days before planting of soybean. Also Monquero et al. (2010) reported that 20 days or more are the best time to desiccate $B$. brizantha before planting soybeans to avoid yield loss. Constantin et al. (2009) and Nascente and Crusciol (2012) suggest that cover crop desiccation should be done with more than 10 days before planting to avoid possible yield reduction caused by the herbicide.

In relation to corn crop, there was not an effect of the cover crops species and desiccation time on the corn population (Table 4). There was an interaction between cover crops and desiccation time for number of ears per plant, number of grain per ear, 100 -grain weight and grain yield (Table 5). Between millet and common bean there was not a significant effect on the number of ears per plant; number of grain per ear and 100-grain weight had similar values in both time of cover crop desiccation. However, for common bean the corn grain yield was similar in both time of cover crop desiccation and under miller the corn grain yield was higher when desiccation time was done at corn planting day $\left(10,013 \mathrm{~kg} \mathrm{ha}^{-1}\right)$ than 15 days before planting $\left(8,044 \mathrm{~kg} \mathrm{ha}^{-1}\right)$. This could have happened because millet has fast straw degradation after glyphosate application and possible fast release of nutrients, as reported by Crusciol et al. (2010) and Monquero et al. (2010). In this sense, desiccation done at corn planting day probably released nutrients that meet the needs of the crop better than desiccation done 15 days before and it also allows higher corn grain yield.

Regarding the cover crop Brachiaria brizantha it was observed that desiccation done at corn planting day reduced number of ears per plant $(1,01)$, number of grain per ear (387), 100-grain weight (29) and as a result the corn grain yield $\left(3,736 \mathrm{~kg} \mathrm{ha}^{-1}\right)$ (Table 5$)$. This grass takes longer to dry completely after glyphosate application and the absorption of herbicide may have remobilized in the rhizosphere, resulting in decreased production of the non-target plant (Yamada and Castro, 2007). According to Coupland and Lutman (1982) in glyphosate applications near the planting time, there is the possibility of root exudation of herbicides from cover crops to corn. Besides, $B$. brizantha has a high relation $\mathrm{C} \mathrm{N}$ and during the process of straw degradation, it is likely that there is $\mathrm{N}$ immobilization, which can cause a lack of this nutrient for corn plants and damage corn development. In this sense, Yamada and Castro (2007), Monquero et al. (2010) and Nascente et al. (2012) reported that due to the

Table 4 - Plant population (POP), number of ear per plant (EP), number of grain per ear (Grain), 100-grain weight (W100) and yield of corn as a function of the cover crops and desiccation time of these cover crops (days before planting, DBP)

\begin{tabular}{|c|c|c|c|c|c|}
\hline Treatments & POP & EP & Grain & W100 & YIELD \\
\hline Cover crops & $\left(\right.$ plant ha $\left.{ }^{-1}\right)$ & $\left(\mathrm{n}^{\mathrm{o}}\right.$ per plant $)$ & $\left(n^{\circ}\right.$ per ear $)$ & (grams) & $\left(\mathrm{kg} \mathrm{ha}^{-1}\right)$ \\
\hline Brachiaria brizantha & $53105 \mathrm{a}^{*}$ & $1.07 \mathrm{a}$ & $440 \mathrm{~b}$ & $32 \mathrm{~b}$ & $5843 \mathrm{~b}$ \\
\hline Millet & $58012 \mathrm{a}$ & $1.18 \mathrm{a}$ & $516 \mathrm{a}$ & $34 \mathrm{ab}$ & 9029 a \\
\hline Common bean & $55581 \mathrm{a}$ & $1.13 \mathrm{a}$ & $501 \mathrm{a}$ & $36 \mathrm{a}$ & $8719 \mathrm{a}$ \\
\hline \multicolumn{6}{|c|}{ Desiccation time } \\
\hline $15 \mathrm{DBP}$ & $55927 \mathrm{a}$ & $1.12 \mathrm{a}$ & $492 \mathrm{a}$ & $34 \mathrm{a}$ & $8170 \mathrm{a}$ \\
\hline \multirow[t]{2}{*}{0 DBP } & $55205 \mathrm{a}$ & $1.12 \mathrm{a}$ & $478 \mathrm{a}$ & $34 \mathrm{a}$ & $7557 \mathrm{a}$ \\
\hline & \multicolumn{5}{|c|}{ ANOVA ( F probability) } \\
\hline Cover crops (CC) & 0.1127 & 0.3815 & 0.0410 & 0.0431 & 0.0158 \\
\hline Desiccation time (DT) & 0.1428 & 0.3378 & 0.2351 & 0.1445 & 0.0416 \\
\hline $\mathrm{CC} \times \mathrm{DT}$ & 0.0954 & 0.0181 & 0.0192 & 0.0240 & 0.0279 \\
\hline
\end{tabular}

* Means followed by the same letter vertically do not differ by Tukey's test at 5\% probability. 
Table 5 - Interactions for number of ear per plant, number of grain per ear, 100-grain weight and yield of corn plants as affected by cover crops and desiccation time

\begin{tabular}{|l|c|c|}
\hline \multirow{2}{*}{\multicolumn{1}{|c|}{ Cover crops }} & \multicolumn{2}{c|}{$\begin{array}{c}\text { Desiccation time } \\
\text { (days before planting) }\end{array}$} \\
\cline { 2 - 3 } & \multicolumn{1}{|c|}{15} & 0 \\
\hline \multirow{2}{*}{ Brachiaria brizantha } & $1.12 \mathrm{a} \mathrm{A}^{*}$ & $1.01 \mathrm{~b}$ B \\
\hline Millet & 1.13 a A & 1.22 a A \\
\hline Common bean & 1.12 a A & 1.13 a A \\
\hline & Number of grain per ear \\
\hline Brachiaria brizantha & 493 a A & 387 b B \\
\hline Millet & 491 a A & 540 a A \\
\hline Common bean & 493 a A & 508 a A \\
\hline & \multicolumn{2}{|c|}{100 grain weight } \\
\hline Brachiaria brizantha & 34 a A & 29 b B \\
\hline Millet & 32 a A & 36 a A \\
\hline Common bean & 35 a A & 36 a A \\
\hline & \multicolumn{2}{|c|}{ Yield } \\
\hline Brachiaria brizantha & 7949 a A & 3736 b B \\
\hline Millet & 8044 a B & 10013 a A \\
\hline Common bean & 8516 a A & 8922 a A \\
\hline
\end{tabular}

* Means followed by the same letter, lower case vertically or upper case horizontally, do not differ by Tukey's test at $5 \%$ probability.

systemic nature of the effect of glyphosate on cover plants or weeds, it is slow and takes a few days to completely kill these plants. As $B$. brizantha is less sensible to glyphosate and take more days to die, it is very important to wait two to three weeks between desiccation and planting of annual crops. Also Constantin et al. (2009) reported that it is necessary to have an interval between glyphosate application and corn planting to prevent corn grain loss. This interval can avoid the herbicide remobilization to the corn plants and the possible allelopathic effect of cover crops or nitrogen immobilization, as well as provide rapid and vigorous development of succeeding crops. The benefits of managing the cover crop before planting agricultural crops with the use of herbicides are: reduction of competition for water in the early crop development; promotion of the decomposition of cover crop residues or weeds, which can provide nutrients for the crop; improvement of the uniformity of planting; reduction in possible allelopathic effects of cover crops or weeds, and promotion of increased productivity (Torkura and Nóbrega,
2006; Borghi and Crusciol, 2007; Nascente and Crusciol, 2012).

Summarizing, it could be observed that glyphosate acts differently in the cover crops with a consequent distinct effect of the timing of desiccation on both crops. In soybean it is necessary to apply the herbicide 15 days before planting, with common bean and millet being the cover crops which allowed the highest grain yield. For corn, common bean should be desiccated anytime between 15 and 0 days before planting. Millet may be desiccated at planting and $B$. brizantha should be controlled 15 days before planting corn.

\section{ACKNOWLEDGEMENTS}

The authors would like to thank Brazilian Agricultural Research Corporation -EMBRAPA for their financial support.

\section{LITERATURE CITED}

BORGHI, E.; CRUSCIOL, C. A. C. Produtividade de milho, espaçamento e modalidade de consorciação com Brachiaria brizantha em sistema plantio direto. Pesq. Agropec. Bras., v. 42, n. 2, p. 163-171, 2007.

CONAB. Acompanhamento da safra brasileira Disponível em: <http://www.conab.gov.br >. Acesso em: 16 set. 2012.

CONSTANTIN, J. et al. Influência do glifosato na dessecação de capim-braquiária e sobre o desenvolvimento inicial da cultura do milho. Planta Daninha, v. 26, n. 3, p. 627-636, 2008.

CONSTANTIN, J. et al. Sistemas de manejo de plantas daninhas no desenvolvimento e na produtividade da soja. Bragantia, v. 68, n. 1, p. 125-135, 2009.

COUPLAND, D.; LUTMAN, P. Investigations into the movement of glyphosate from treated to adjacent untreated plants. Ann. Appl. Biol., v. 101, n. 2, p. 315-321, 1982.

CRUSCIOL, C. A. C. et al. An innovative crop-forage intercrop system: early cycle soybean cultivars and palisadegrass. Agron. J., v. 104, n. 4, p. 1085-1095, 2012.

CRUSCIOL, C. A. C. et al. Benefits of integrating crops and tropical pastures as systems of production. Better Crops, v. 94, n. 2, p. 14-16, 2010.

FERREIRA, A. et al. Produção de biomassa por cultivos de cobertura do solo e produtividade do algodoeiro em plantio direto. Pesq. Agropec. Bras., v. 45, n. 6, p. 546-553, 2010. 
GRISSO, R. B. et al. Planter/Drill considerations for conservation tillage systems. Virginia Cooperative Extension Publication. 2009. p.442-457. Available at: $<$ http://pubs.ext.vt.edu/442/442-457/442-457.html $\geq$. Acessed in: 18 Jan. 2012.

LOPES, P. R. C. et al. Eficácia relativa de tipo e quantidade de resíduos culturais espalhados uniformemente sobre o solo na redução da erosão hídrica. R. Bras. Ci. Solo, v. 11, n. 1, p. 71-75, 1987.

MONQUERO, P. A. et al. Intervalo de dessecação de espécies de cobertura do solo antecedendo a semeadura da soja. Planta Daninha, v. 28, n. 3, p. 561-573, 2010.

NASCENTE, A. S.; CRUSCIOL, C. A. C. Cover crops and herbicide timing management on soybean yield under no-tillage system. Pesq. Agropec. Bras., v. 47, n. 2, p. 187-192, 2012.

NASCENTE, A. S. et al. Brachiaria ruziziensis and herbicide on yield of upland rice. Planta Daninha, v. 30, n. 4, p. 729-735, 2012.

NASCENTE, A.S. et al. Cover crops and no-till effects on physical fractions of soil organic matter. Soil Till. Res., v. 130, n. 1, p. 52-57, 2013 a.

NASCENTE, A.S. et al. Upland rice yield as affected by previous summer crop rotation (soybean or upland rice) and glyphosate management on cover crops. Planta Daninha, v. 31, n. 1, p. 147-155, 2013b.
NASCENTE, A.S. et al. The no-tillage system and cover crops - alternatives to increase upland rice yield. Eur. J. Agron., v. 45,n. 2, p. 124-131, 2013c.

NUNES, A. S. et al. Épocas de manejo químico de Brachiaria decumbens antecedendo o plantio direto de soja.

Planta Daninha, v. 27, n. 2, p. 297-302, 2009.

NUNES, U. R. et al. Produção de palhada de plantas de cobertura e rendimento do feijão em plantio direto. Pesq. Agropec. Bras., v. 41, n. 6, p. 943-948, 2006.

SAS Institute. Procedure guide for personal computers. Version 5. Cary: 1999.

SULC, R. M.; TRACY, B. F. Integrated crop-livestock systems in the U.S. Corn Belt. Agron. J., v. 99, n. 2, p. 335-345, 2007.

TIMOSSI, P. C. et al. Formação de palhada por braquiárias para adoção do sistema plantio direto. Bragantia, v. 66, n. 4, p. 617-622, 2007.

TOKURA, L. K.; NÓBREGA, L. H. P. Alelopatia de cultivos de cobertura vegetal sobre plantas infestantes. Acta Sci.

Agron., v. 28, n. 3, p. 379-384, 2006.

YAMADA, T.; CASTRO, P. R. C. Efeitos do glifosato nas plantas: implicações fisiológicas e agronômicas. Inf. Agron., v. 119, n. 1, p. 1-32, 2007. 